대전 선병원 내과

윤영걸, 방도석, 박범철, 이성훈, 김재수, 박 열, 홍영철, 박상민, 고경태, 한상훈, 박상훈, 임준철, 나동집

\title{
Localized Pulmonary Edema in Patient with Severe Mitral Regurgitation
}

Young Gul Yoon, M.D., Do Seok Bang, M.D., Bum Chul Park, M.D., Sung Hoon Lee, M.D., Jae Su Kim, M.D., Yol Park, M.D., Young Chul Hong, M.D., Kyoung Tae Ko, M.D., Sang Min Park, M.D., Sang Hoon Han, M.D., Sang Hoon Park, M.D., Jun Cheol Lim, M.D., and Dong Jib Na, M.D.

Department of Internal Medicine, Sun Hospital, Dae Jeon, Korea

\begin{abstract}
An 82-year-old female non-smoker with a history of hypertension presented with increasing dyspnea, cough and some purulent sputum without fever. Upon admission, the patient was in a distressed condition. Auscultation revealed diminished breath sounds with no rales over the right lung. An examination of the heart revealed a regular rhythm and a systolic murmur radiating from the apex of the heart. There was no pitting edema in the lower extremities.

The blood tests showed mild leukocytosis and an increased C-reactive protein level. The $\mathrm{O}_{2}$ saturation was $98 \%$ whilst breathing room air. The electrocardiogram demonstrated sinus tachycardia. The chest radiograph showed a moderate cardiomegaly, right lobe infiltrates, and blunting of the both costophrenic sulcus suggesting a small pleural effusion. Three days after admission, the symptoms became slightly aggravated despite being treated with empirical antibiotics for presumed community-acquired pneumonia. Transthoracic color Doppler echocardiography indicated an ejection fraction of $48 \%$, mild left ventricular enlargement, and moderate left atrial enlargement resulting in severe mitral regurgitation. The clinical symptoms and right pulmonary edema resolved quickly with intravenous furosemide treatment. (Tuberc Respir Dis 2005: 59: 432-435)
\end{abstract}

Key words : Pulmonary edema, Mitral regurgitation

\section{증 례}

환 자 : 82 세, 여자

주 소 : 호흡 곤란 및 기침

병 력 : 82세 여자가 내원 4 일전부터 시작된 호흡 곤란을 주소로 입원하였다. 기침과 약간의 화농성 객 담은 있었으나 열은 없었다.

과거력 : 고혈압 치료를 받고 있으며 결핵 및 당뇨는 없었다

이학적 소견 : 급성 병색을 보였으며 혈압 $170 / 90 \mathrm{mmHg}$, 맥박수 116 회/분, 호흡수 26 회/분, 체온 $36.8{ }^{\circ} \mathrm{C}$ 이였 고, 청진시 우측폐의 호흡음이 감소되고 수포음은 들 리지 않았으며 폐첨부위에서 수축기 심잡음이 들렸

Address for correspondence : Dong Jib Na, M.D. Department of Internal Medicine, SUN HOSPITAL 10-7 Mok-Dong, Jung-Gu, Dae-Jeon, 301-725 Korea Phone : 82-42-220-8800 Fax : 82-42-335-1431 E-mail : djna@sunhospital.com

Received : Jun. 16. 2005

Accepted : Sep. 2. 2005
다. 복부, 사지 및 신경학적 검사는 정상이었다.

검사실 소견 : 말초 혈액 검사상 백혈구 $12,000 / \mathrm{mm}^{3}$ (호중구 $83.4 \%$, 호산구 $0.1 \%$, 림프구 $1.2 \%$, 단핵구 $0.8 \%$ ), 혈색소 $11.5 \mathrm{~g} / \mathrm{dl}$ 적혈구 용적률 $34.2 \%$, 혈소 판 $276,000 / \mathrm{mm}^{3}$, 적혈구 침강속도 $38 \mathrm{~mm} / \mathrm{hr}$ 및 $\mathrm{CRP}$ $2.96 \mathrm{mg} / \mathrm{dl}$ 이었다. 생화학 검사상 Albumin $3.0 \mathrm{~g} / \mathrm{dl}$, AST/ALT 26/16 IU/L, Bilirubin 0.3 mg/dl, Na/K/Cl $147 / 4.2 / 98 \mathrm{mEq} /$ 이며 갑상선 검사는 정상이었다. 심 전도상 동성 빈맥이며 실온에서의 동맥혈 가스 분석 상 $\mathrm{pH} 7.404, \mathrm{PCO}_{2} 41.6 \mathrm{mmHg}, \mathrm{PO}_{2} 103.6 \mathrm{mmHg}$, $\mathrm{HCO}_{3}^{-} 26.1 \mathrm{mmol} / \mathrm{L}, \mathrm{O}_{2}$ Saturation 98\%이었다.

방사선 소견: 내원시 단순 흉부 촬영(Figure $1 \mathrm{~A}, 1 \mathrm{~B}$ ) 상 심비대 및 우상엽과 우중엽부위에 침윤 소견이 보 이며 양쪽에 소량의 늑막액 의심되었다.

심장 초음파(Figure 3)는 Ejection fraction $48 \%$, 좌심실 및 좌심방의 확장 및승모판에서 역류된 혈류 가 좌심방의 후벽까지 도달하는 중증의 승모판 역류 소견이 관찰되었다.

객담 검사 : 그람 염색 및 배양, 항산균 도말 모두 음 
성이며 Mycoplasma Ab 음성, Cold agglutinin 1:4 이 었다.

임상 경과 : 입원시 발열은 없었으나, 백혈구 증가, 흥부사진 소견상 우측폐의 침윤과 소량의 화농성 객 담등으로 폐렴을 의심하였으며 늑막액은 양이 적어
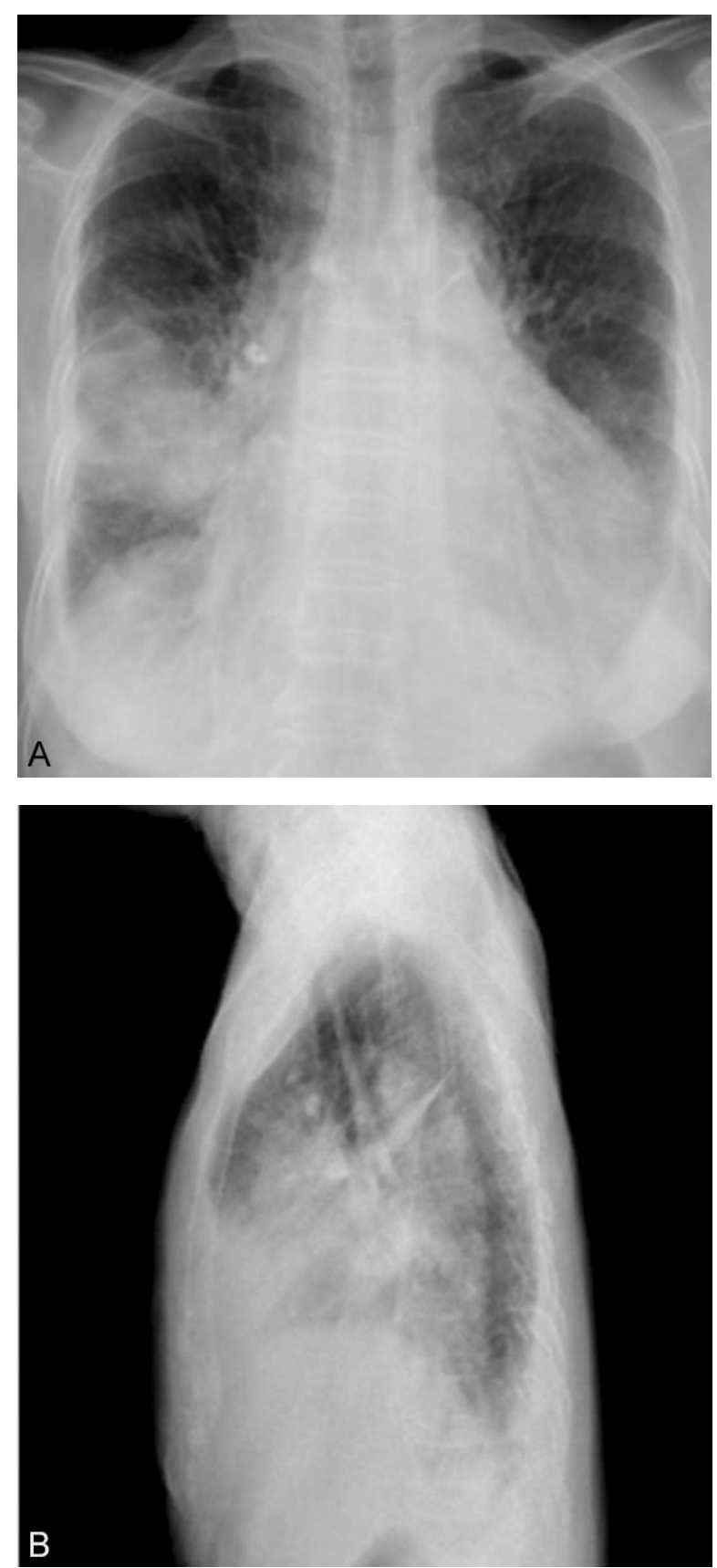

Figure 1. Chest radiographys at admission: posteroanterior (A) and right lateral (B) films showing right lung infiltration, cardiomegaly, and blunting of the both costophrenic sulcus.
서 검사하지 않았다. 경험적 항생제를 투여후에도 호 흡 곤란은 지속 되었으며 흉부 방사선의 침윤 소견도 (Figure $2 \mathrm{~A}$ ) 감소되지 않았다. 입원 3일째 심장 초음파 시행결과 중증의 승모판 역류 소견을 보여 furosemide 정주 투여후 다음날 흥부 방사선 소견상(Figure 2B)
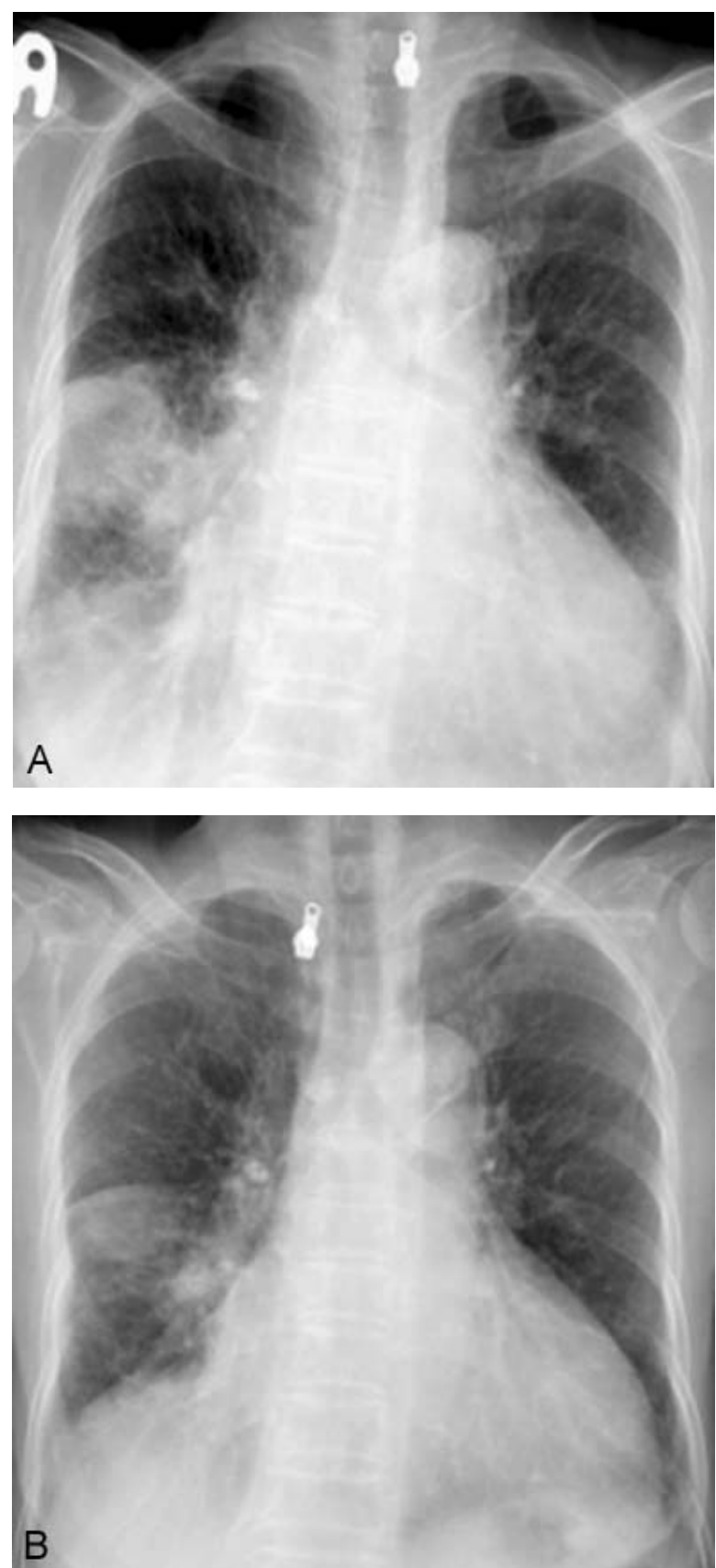

Figure 2. On 3 days after hospitalization, chest radiography demonstrating unchanged right lobe infiltra tion (A) which improved notably on the following morning after intravenous furosemide treatment (B). 


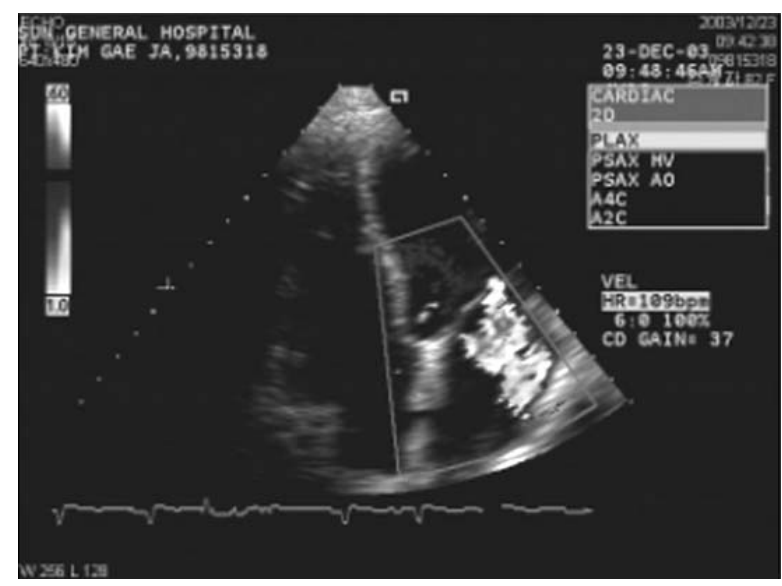

Figure 3. Transthoracic color Doppler echocardiogram demonstrating severe mitral regurgitation with eccentric jet directed toward the left atrium

침윤 소견이 급격히 감소했으며 호흡 곤란도 호전 되 었다.

\section{고 찰}

심인성 폐부종의 전형적인 흉부 방사선 소견은 양 측성의 폐포 및 간질성 폐부종의 형태 (alveolar and interstitial pulmonary edema), 폐문부 주위의 폐혈관 의 확장과 역전형의 폐혈류 분포(cephalized blood flow)이지만 일부의 경우에서 비대칭적인 부종의 형 태로 나타날 수 도 있다.

비대칭 형태의 부종의 원인으로는 1 . 중력에 의한 효과로 장기간 옆으로 누워있는 경우 2. 폐관류의 이 상 (폐색전증, Sweyer-James syndrome) 3. 폐정맥의 배출 장해 (atrial myxoma, unilateral veno-occlusive disease) 4. 늑막강내의 압력의 변화 (re-expansion pulmonary edema after pleurocentesis) 5. 폐환기의 장애 (bronchial obstruction)등이다 ${ }^{1-2}$.

Schnyder는 심한 승모판 폐쇄 부전 환자 131명중 12 명에서 $(9 \%)$ 에서 우상엽에 국한된 폐부종을 보 고하였는데 이전의 보고 ${ }^{3,5}$ 와 비교하면 유병율이 높 아졌다. 또한 초기의 폐렴 진단이 틀린 이유로 심질 환의 가능성을 고려 하지 않은것으로 설명 하였다.

승모판 폐쇄 부전으로 인한 국소적 폐부종의 발생 기전으로 승모판과 폐정맥사이의 해부학적인 특징으
로 설명 할 수 있는데, 심한 승모판 폐쇄 부전의 경 우 좌심실 수축기에 발생한 혈액중 좌심방쪽으로 역류된 혈류가 해부학적 특징으로 우상엽 폐정맥 의 기시부를 향하게 되고 결국 Staring forces가 증 가되면 우상엽에 국소적인 형태의 부종이 나타난 다. 우중엽 정맥이 때로 우상엽의 정맥과 함께 합 쳐져서 좌심방으로 유입 되는 경우도 있는데 이때 는 우상엽 및 우중엽에도 국소적 침윤이 나타날 수 있다 6 .

본 증례는 자의에 따라 고혈압약을 복용했으나 평 소 호흡 곤란이나 부종등의 증상이 없던 환자로 갑작 스런 호흡 곤란과 흉부 사진상 우상엽과 우중엽의 침 윤 소견등으로 처음에는 폐렴이라고 생각했었다. 입 원후 항생제 치료에도 불구하고 증상의 호전이 없던 중 심장초음파 시행결과 심한 승모판 폐쇄 부전에 대 한 이뇨제 사용후 비교적 빨리 증상이 호전된 경우이 다. 따라서 흥부 사진상 전형적인 폐부종의 형태가 아 니었지만 임상 경과와 치료에 대한 반응으로 볼때 심 한 승모판 폐쇄 부전에 의한 우측폐의 국소적인 폐부 종으로 생각한다.

\section{요 약}

승모판 폐쇄 부전증에 의한 심부전의 경우 대부 분 양측폐에 대칭적으로 폐부종이 발생하지만 일 부의 경우 국소적인 폐부종 형태로 나타날 수 있으 며 대부분 우상엽에 발생하며 우중엽에 동반되기 도 한다

승모판 폐쇄 부전증 환자의 흥부 방사선 소견상 일 측성 침윤이 보일때 폐렴과 국소적인 폐부종을 감별 해야 할 것이다.

\section{참 고 문 헌}

1. Calenoff L, Kruglic GD, Woodruff A. Unilateral pulmonary edema, Radiology 1978;126:19-24.

2. Milne EN, Pistolesi M, Miniati M, Giuntini C. The radiological distinction of cardiogenic and noncardiogenic edema. AJR Am J Roentgenol 1985;144:879-94. 
3. Bahl OP, Oliver GC, Rockoff SD, Parker BM. Localized unilateral pulmonary edema: an unusual presentation of left heart failure. Chest 1971;60:277-80.

4. Schnyder PA, Sarraj AM, Duvoisin BE, Kapenberg L, Landry MJ. Pulmonary edema associated with mitral regurgitation: prevalence of predominant involvement of the right upper lobe. AJR Am J Roentgenol 1993;
161:33-6.

5. Gurney JW, Goodman LR. Pulmonary edema localized in the right upper lobe accompanying mitral regurgitation. Radiology 1989;171:397-9.

6. Alarcon JJ, Guembe P, de Miguel E, Gordillo I, Abellas A. Localized right upper lobe edema. Chest 1995;107: 274-6. 